W I L L I A M G . G A LE

Brookings Institution

\author{
J OH N SABELHAU S
}

Congressional Budget Office

\title{
Perspectives on the Household Saving Rate
}

In SEPTEMBeR AND OCtOBeR 1998, the personal saving rate as measured in the national income and product accounts (NIPAs) dipped below zero for the first time since the Great Depression. For the entire year, personal saving totaled just 0.5 percent of personal disposable income, the lowest rate since 1933. And in the advance estimate for the first quarter of 1999, the personal saving rate fell to -0.5 percent. These results are just the latest steps in the decline of the NIPA personal saving rate, which, after averaging 7.6 percent in the $1960 \mathrm{~s}, 8.2$ percent in the $1970 \mathrm{~s}, 6.7$ percent in the 1980s, and 4.8 percent in 1990-94, fell to 3.0 percent in 1996 and 2.2 percent in 1997. Although both academic publications and the popular press have repeatedly warned of a saving crisis over the last twenty years, the virtual disappearance of personal saving since 1998 has brought the issue back into the limelight.

At least three different views of the decline in personal saving have been aired. One group, with a focus on long-term growth, views the low saving rate as bad news and worries that saving will stay low. Holders of this view believe that low saving rates signify dangerously low levels of capital accumulation. At a macro level, this breeds increasing dependence

The views expressed in this paper are our own and should not be interpreted as those of the Brookings Institution or the Congressional Budget Office. For very helpful comments on an earlier version of this paper we thank Barry Bosworth, David Bradford, Robert Hall, William Nordhaus, Maria Perozek, Charles Schultze, Joel Slemrod, and Eugene Steuerle. We also thank Michael Simpson for extensive assistance with the data and Saran Holden in the Flow of Funds Section at the Federal Reserve Board for guidance on using the flow of funds accounts. William Gale gratefully acknowledges research support from the National Institute on Aging. 
on fickle foreign capital; at a micro level, it raises fears that households are not saving enough for retirement or other purposes.

A second group, focused on sustaining short-term aggregate demand, sees significant good news in the low saving rate and worries that saving will rebound. Adherents of this view argue that the decline in personal saving and the accompanying rise in consumption have helped fuel the economic expansion in the United States and helped prop up the global economy. They worry that households are now stretched thin and will soon retrench, driving the U.S. and global economies into a tailspin.

The third view is perhaps best summarized by William Nordhaus: "Our tools for measuring saving and investment are stone-age definitions in the information age." This view is rooted in the observations that standard measures of aggregate saving correspond weakly at best to the concepts of saving that drive economic models and analysis, that empirical measures of saving are inherently elusive and often arbitrary, and that coming to grips with different economic issues may require the examination of different measures of saving. This view does not rule out the hypothesis that saving is too low or that a consumption binge is propping up the economy, but holders of this view would be unlikely to draw these-or any other-conclusions on the basis of official saving aggregates alone.

In this paper we reexamine secular and recent trends in saving in a spirit consistent with the third view. Our central goal is to delineate several alternative conceptual measures of saving and present evidence on how each has evolved over time. We do not attempt to determine the causes or the consequences of the saving decline; indeed, some of our measures suggest that saving is rising rather than falling. ${ }^{2}$

We begin by examining the various ways in which saving can be defined and noting that saving measures can vary in scope and in level of aggregation. We highlight the point that different concepts and measures of saving may be most relevant for answering different questions. Understanding how each of various saving measures has evolved can inform numerous aspects of policy and research. Indeed, it is difficult to see how relevant conclusions about saving can be reached without a detailed understanding of these issues.

1. Nordhaus (1995).

2. For analyses of the determinants of recent trends in saving behavior, see Parker (1999), the citations therein, the comments on that paper by Laibson and Lusardi, and Bosworth, Burtless, and Sabelhaus (1991). 
Next we examine the standard measures of saving stemming from the NIPAs. To obtain measures that correspond more closely to economic concepts of saving, we alter the treatment of durable goods, inflation, retirement accounts, and tax accruals. We also show that the distinctions between personal and corporate saving are thin and somewhat arbitrary, and thus we tend to focus on total private (personal plus corporate) saving. We find that the adjusted measures of personal and private saving are significantly higher than the official data and have fallen by a much smaller amount over the last two to three decades. We also note an increase in government saving that offsets the decline in personal saving.

We then turn to data from the national balance sheets that are part of the flow of funds accounts (FFAs). This data source also shows a decline in saving over time, due primarily to a reduction in net acquisition of nontax-preferred financial assets. Acquisitions of tax-preferred financial assets, household accumulations of durable goods, and trends in borrowing have remained roughly constant in recent years.

To provide another perspective, we augment the FFA measures of household saving with data on real capital gains. We show that, over the past forty years, capital gains have dominated measured saving as a source of household wealth accumulation, and that, if all capital gains are included as saving, the household saving rate is at its highest level in the past forty years, not its lowest. We discuss but do not resolve whether and under what circumstances it is appropriate to include capital gains in measures of saving.

We conclude by noting other items that could be added to saving rates, including human capital, research and development, and other intangible capital. Thus we make no claim to having captured "the" saving rate. Rather, we conclude that different measures of saving can provide different but complementary perspectives on the evolution of the economy and that an understanding of these perspectives is a crucial input to any broader interpretation of the causes or consequences of trends in saving behavior.

\section{What Is Saving?}

Generally, saving may be thought of as resources created or outputs produced in the current period that are not consumed in the current period but rather are made available for future consumption. With this idea in 
mind, saving is alternatively defined as income minus consumption, or the change in wealth, or the supply of capital. Given comprehensive and consistent definitions of each of these terms, each definition of saving would represent the same concept and give rise to similar empirical measures. Empirically, however, several important issues arise.

First, even if one approach to defining saving-for example, income less consumption-is accepted to the exclusion of others, these terms, too, can be defined in different ways. For example, Nordhaus traces two historical definitions of income. ${ }^{3}$ Hicksian income is based on production and measures the maximum amount of resources that could be consumed in the current period while leaving the net capital stock intact. Fisherian income is the equivalent of a consumption annuity and measures the maximum amount of resources that could be consumed in the current period while still allowing for at least as much consumption in each successive period. Although Weitzman shows special circumstances under which these measures are equivalent, ${ }^{4}$ Nordhaus shows that in general they will differ, and empirically they differ significantly. ${ }^{5}$ As a result, measures of saving out of Hicksian income (that is, Hicksian income less consumption) are empirically quite different from measures of saving out of Fisherian income.

Second, saving measures can differ in scope. A narrow measure of saving, often used in microeconomic studies of households, focuses on flows of financial assets and debt. A very broad measure of saving would focus on changes in the stock and value of financial, physical, intangible, human, public, natural, and environmental capital. ${ }^{6}$ Each alternative measure of the scope of saving implies alternative measures of income, capital, wealth, and so on. Likewise, each alternative definition of wealth, or of income and consumption, implicitly defines an associated measure of saving.

Saving can be measured in real or nominal terms and either gross or net of depreciation. For most economic purposes, however, it is undoubtedly most appropriate to measure saving in real terms and net of depreciation. Saving measures can also vary by level of aggregation across individuals, businesses, and governments.

3. Nordhaus (1995).

4. Weitzman (1976).

5. Nordhaus (1996).

6. Eisner (1988) surveys broad measures of saving that various authors have employed. 
Which measure of saving is most appropriate to employ may well depend on why the data are being examined in the first place. To understand how well households are preparing for retirement, for example, it would be logical to focus on personal wealth measures, including social security and medicare benefits. In contrast, if the goal is to examine government policies that encourage saving for retirement, it would be logical to include their effects on government saving as well as on private saving, since policy that raised private saving but reduced government saving by more might not be considered effective.

Alternatively, if the goal is to understand the share of aggregate production that society is devoting to investment in future production, it makes sense to include not only saving as conventionally measured but also investment in human capital, research and development, and other forms of intangible capital. Whether capital gains should be included in the calculation is controversial and may well depend on the source of the gain, as discussed below.

These observations do not point to a unique, well-defined measure of saving. But they do suggest links between various economic concepts and appropriate measures of saving and the importance of closely examining the measure and concept used.

\section{Saving in the National Income and Product Accounts}

The NIPAs are designed to measure current production, the income arising from that production, and the allocation of income across the household, corporate, and government sectors. NIPA saving measures are devised as part of this broader framework and therefore may not correspond well with concepts and measures of saving in economic models.

\section{Personal Saving}

NIPA personal saving is meant to represent the portion of current production made available by the household sector for the purchase of new capital. ${ }^{7}$ The household sector includes individuals and families, pension

7. For further discussion of saving in the NIPAs, see Antoniewicz and Engen (1994), Auerbach (1985), Boskin (1986), Bradford (1990, 1991), Ruggles and Ruggles (1983), Ruggles (1993), and Holloway (1989). The Bureau of Economic Analysis has been very respon- 
funds, life insurance, trust funds, not-for-profit organizations, and unincorporated businesses.

Formally, NIPA personal saving is measured as the difference between personal disposable income and personal consumption outlays. Personal disposable income is simply personal income less tax and nontax payments by the household sector to governments. Personal income is defined as the sum of wage and salary disbursements, other labor income, net proprietor's income from unincorporated businesses, net rental income, personal interest and dividend income, and transfer payments, less personal contributions for social insurance (social security and medicare). The vast bulk of personal consumption outlays consists of expenditures on durables, nondurables, and services. Interest paid by consumers to businesses and net personal transfer payments to foreigners are also included in outlays.

Several features of the NIPA personal saving data are worth noting. First, accrued and realized capital gains are excluded. A realized gain is simply an exchange of one asset for another, and an accruing gain, although it reflects an increase in the purchasing power of the asset holder, is not considered to raise current production in the NIPA framework.

Second, all contributions to and interest and dividend earnings on private pensions and 401(k) plans are included in NIPA personal saving. Employee contributions to pensions and 401(k)s are included as part of wage and salary disbursements. Employer contributions are counted as part of other labor income, as are the interest and dividend earnings (less expenses) of pension and 401(k) plans. To avoid double counting, payments of pension benefits are not included as income. Individual retirement accounts (IRAs) and Keogh accounts are treated similarly: contributions and interest and dividend earnings represent personal saving, but withdrawals do not count as personal income.

The treatment of pensions creates an important difference between households' view of their own wealth accumulation and recorded NIPA saving. For workers enrolled in defined benefit pension plans, the time pattern of benefit accruals may be quite different from the patterns of contributions and investment earnings. To take an extreme example, a worker who takes a job at age 30 and is immediately vested in a pension plan that pays a real benefit of $\$ 50,000$ per year upon turning 65 accumulates a large

sive to past commentary about how investment is measured and how saving is allocated across sectors in the NIPAs (see Holloway, 1989; Larkins, 1999). 
amount of pension wealth upon starting the job. The recorded NIPA saving, however-the employer and employee contributions and the interest and dividend earnings-will generally occur much later.

This is not to say that the NIPA method of recording pension saving is inappropriate. The enrolling of the worker in the pension plan generates no net pension saving - it merely creates a future pension asset for the worker that is exactly offset by a pension liability for the firm. Accordingly, the NIPAs record no saving as a result of the worker enrolling in the plan, even though the worker sees a large increase in pension wealth. The net saving occurs when the pension is funded by contributions and when the pension balance grows with interest and dividends. These actions pay down the pension liability but do not affect the pension benefit. Accordingly, these items are recorded in NIPA saving. ${ }^{8}$

Third, the NIPAs treat public pension and insurance funds in exactly the opposite manner from private funds. Contributions and earnings of federal, state, and local government pension and insurance funds are not treated as personal saving, and so the benefit payments from those funds are treated as income when received. Likewise, social security contributions are not counted in personal saving (they are subtracted as part of personal tax and nontax payments), and so social security benefits are counted as personal income (specifically, as transfer payments).

Fourth, the NIPAs treat consumer durables and owner-occupied housing differently, even though both are physical assets and both provide a stream of consumption benefits in the future. Spending on owner-occupied housing is considered saving: the net imputed rental income is included in the rental income component of personal income, and the imputed space rental is included in the services component of consumption expenditures. In contrast, purchases of other consumer durables count as current consumption outlays.

Fifth, the NIPA saving measure includes nominal interest receipts as income and nominal interest payments as outlays. However, in the presence of inflation, only the real component of interest flows should count as income or outlays. Thus, for example, if a corporation pays a household $\$ 100$ in nominal interest, and the inflation rate and the real interest rate are

8. One effect of pensions is not recorded in NIPA saving: the unfunded liability that is created when the pension is created should reduce corporate equity values. But since the NIPA saving measure does not include capital gains, this effect is not included. 
equal, real household sector income and saving are overstated by $\$ 50$ and real corporate income and saving are understated by $\$ 50$.

Sixth, saving in the form of pensions has an implicit tax liability associated with it. ${ }^{9}$ For example, a household that makes a $\$ 100$ tax-deductible contribution to a pension and is permanently in a 20 percent tax bracket should be conceived as having saved only $\$ 80$. The remaining $\$ 20$ is deferred taxes - it represents neither reduced current consumption nor increased future consumption for the household. A similar proportion of interest and dividend earnings on pensions should not be construed as personal saving. NIPA personal saving measures, however, include not only the entire contribution but also interest and dividend earnings on private pensions.

\section{Corporate Saving}

Corporate saving in the NIPAs is the undistributed profits of corporations (that is, after-tax profits less dividends paid to shareholders) plus an inventory valuation adjustment applied to the book value of inventories and a capital consumption adjustment applied to the book value of plant and equipment. These adjustments conform the undistributed profits measure to the replacement cost concept that underlies the NIPAs. Like personal saving, NIPA corporate saving does not adjust interest flows for inflation. We refer to corporate saving as corporate retained earnings, and to private saving as the sum of corporate and personal saving.

From the perspective of economic theory, the line between personal and corporate saving is thin and somewhat arbitrary. Regardless of whether individuals effectively "pierce the corporate veil," ${ }^{10}$ the distinctions that the NIPAs make between personal and corporate saving do not appear to be the most relevant or appropriate for most economic models or analyses of saving. For example, Poterba notes that both corporate dividend payments and corporate share repurchases involve shifting funds from the corporate to the household sector, but they have different effects on sectoral saving in the NIPAs. Capital gains included as part of mutual fund distributions used to be part of personal income, although gains in general are not counted. A few years ago, however, such gains were reclassified as corporate income. The associated revisions increased corporate

9. Auerbach (1985); Bradford (1991); Engen, Gale, and Scholz (1996).

10. See Poterba (1987) for more discussion and citations. 
saving and reduced personal saving but left private saving unchanged. Likewise, the incorporation of Goldman Sachs earlier this year will shift saving from the household sector to corporations.

\section{Trends in NIPA Saving Measures}

Table 1 shows NIPA net domestic investment and sources of funds for investment across economic sectors for various subperiods over the last forty years. Focusing first on the 1990s, personal saving fell from 3.5 percent of GDP in the early 1990s to 0.4 percent by 1998 . However, the table also shows that net private investment increased during the 1990s, from 5.3 percent of GDP in 1990-94 to 8.2 percent in 1998. That is, the decline in measured personal saving was more than offset by increased saving in other sectors. Total government saving rose from -2.0 percent of GDP in 1990-94 to 2.7 percent in 1998. Over the same period, corporate retained earnings rose by 1.2 percent of GDP and net foreign saving by 1.5 percent of GDP.

Taking a longer view, net investment was about 2 percent of GDP lower in 1997-98 than in the 1960s and 1970s. Measured government saving and corporate retained earnings were about the same share of GDP in the late 1990 s as they were in the 1960 s, but personal saving has fallen by about 5 percent of GDP, while net foreign saving has increased by almost 3 percent of GDP.

\section{Adjusted Measures of NIPA Saving}

For the reasons noted above, the raw NIPA data are suspect, and it would be useful to know whether the issues raised earlier affect assessments of trends either in total investment over time or in the allocation of saving across sectors. In this section, therefore, we adjust the NIPA data for several factors.

To incorporate saving and investment in the form of durable goods, we use data on net investment in durables taken from the FFAs. Net investment is measured as the change in the stock of durables and equals new purchases less the estimated depreciation of the existing stock of durables. ${ }^{11}$

11. For further discussion see Auerbach (1985), Congressional Budget Office (1993), Hendershott and Peek (1989), and Wilson and others (1989). 


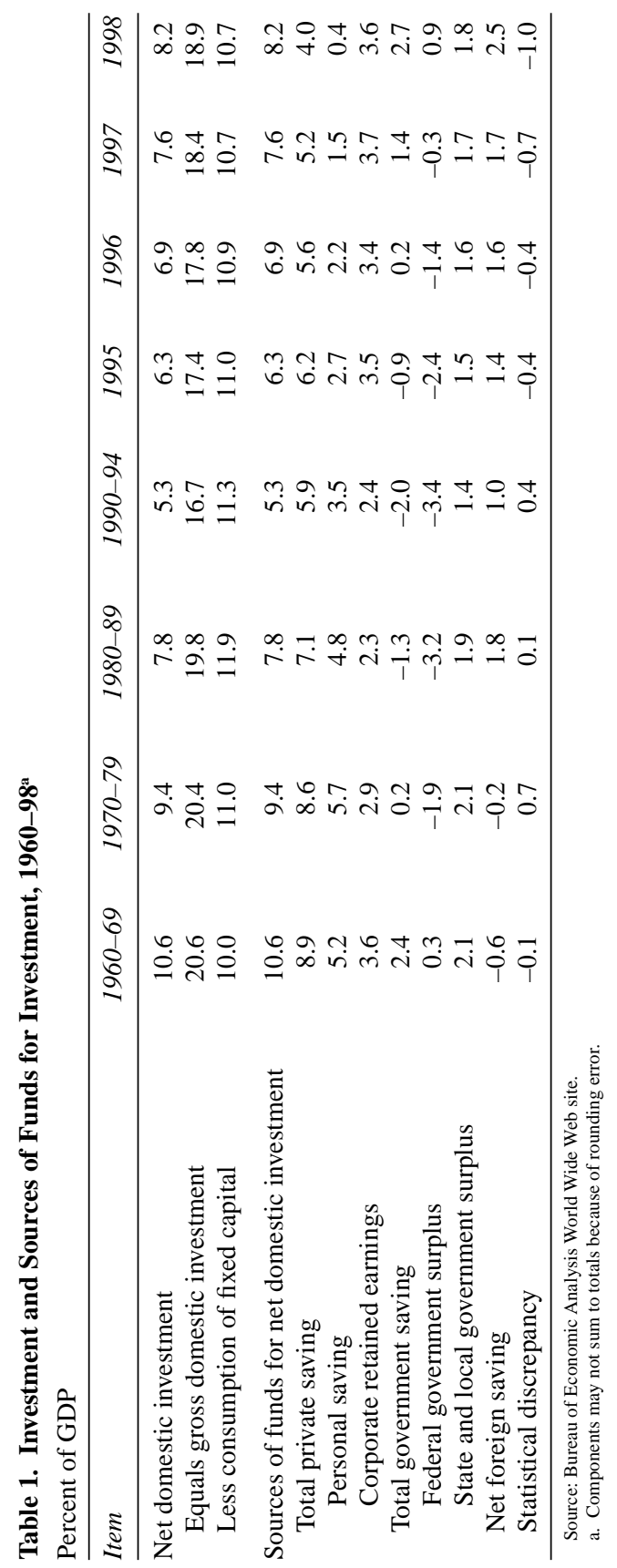


To provide consistent treatment of government and private pensions, we treat government pensions as if they were private pensions. That is, we add contributions and interest earnings to personal saving and exclude benefit payments from personal income. ${ }^{12}$

To measure each sector's NIPA saving in real terms, we subtract from each sector's nominal saving the product of the percentage change in the GDP deflator and the beginning-of-period credit market debt. ${ }^{13}$ Credit market debt, for the household sector, includes debt held by pension funds. We use the GDP deflator to obtain as broad a measure of inflation as possible. However, using the personal consumption expenditure deflator would not change our conclusions significantly. We do not adjust equity holdings for inflation, because the NIPA framework does not include capital gains.

To account for the accrual of tax payments implicit in pension saving, we multiply pension fund saving by an assumed effective tax rate of 20 percent. ${ }^{14}$ We do not claim that this is exactly the correct effective tax rate to employ. Rather, our goal here is to see whether plausible adjustments for tax accruals have significant effects on the evolution or the composition of saving. For simplicity's sake we attribute the entire accruing tax bill to the federal government rather than allocate it across federal, state, and local governments.

The adjusted data in table 2 show the same general trends in the level of national saving as do the raw NIPA data. Both series show net domestic investment rising in the 1990s but remaining below levels attained in the 1960s and 1970s. Because the share of foreign saving financed by foreign investment rose by 2 to 3 percent of GDP over the same period, adjusted net domestic investment financed by domestic saving fell from 12.3 percent of GDP in the 1960s to 8.1 percent in 1998.

12. Formally, we use the flow of funds measure of government pension fund "net acquisitions." As discussed below, the flow of funds approach measures the same concept as do the NIPAs but uses different data and thus differs slightly empirically. Bosworth, Burtless, and Sabelhaus (1991) and Hendershott and Peek (1989) make similar adjustments. Others have decided it is more meaningful to treat accumulations by firms to pay future pension benefits as business saving, and they allocate the saving in defined benefit plans to the business sector to be consistent with the way that the NIPAs allocate saving in government pension plans to the government sector. See, for example, Summers and Carroll (1987) and Poterba (1987).

13. Similar adjustments for inflation have been made by Summers and Carroll (1987), Congressional Budget Office (1993), Hendershott and Peek (1989), and Wilcox (1991).

14. Based on calculations in Engen, Gale, and Scholz (1996). 


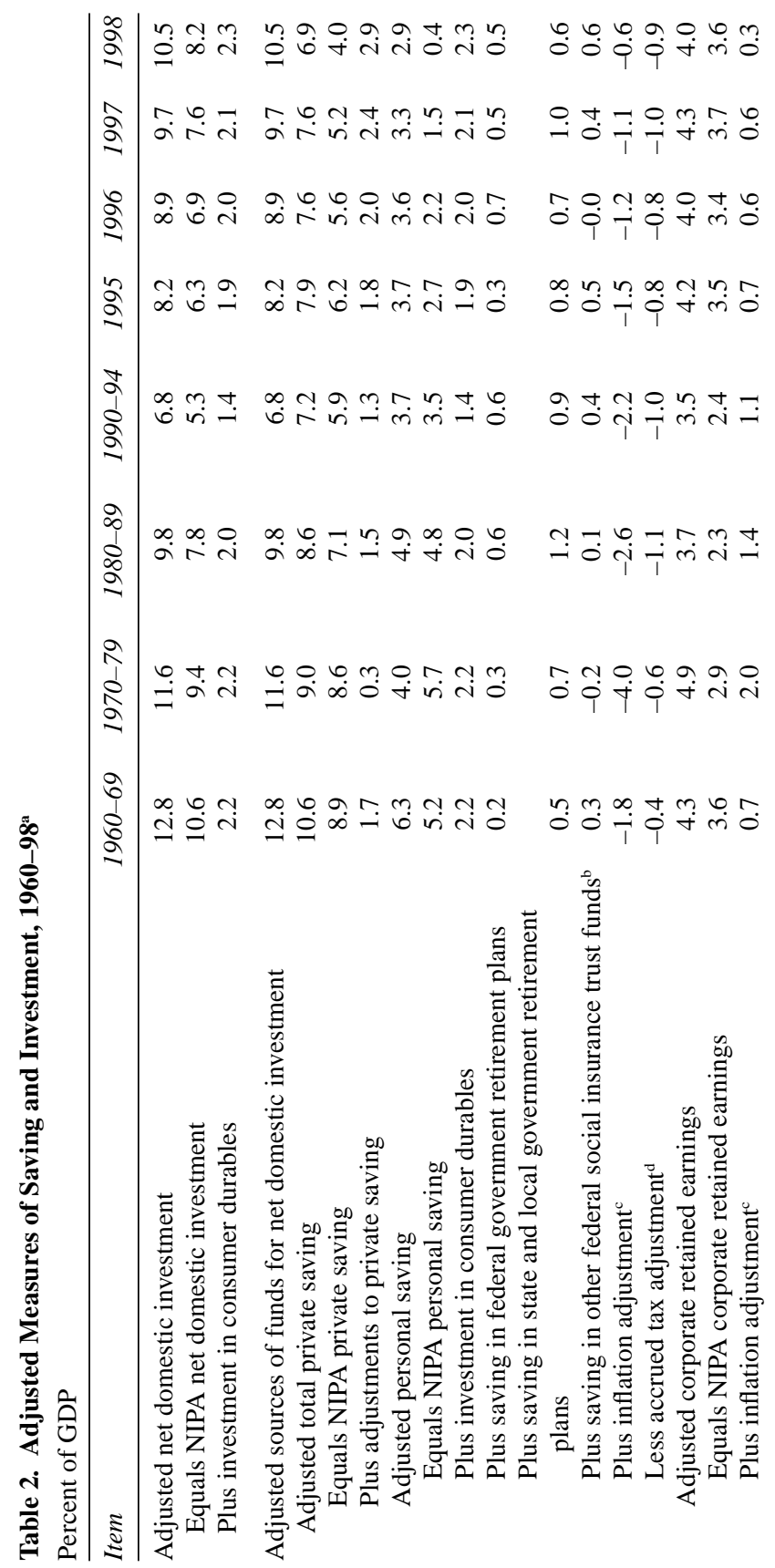




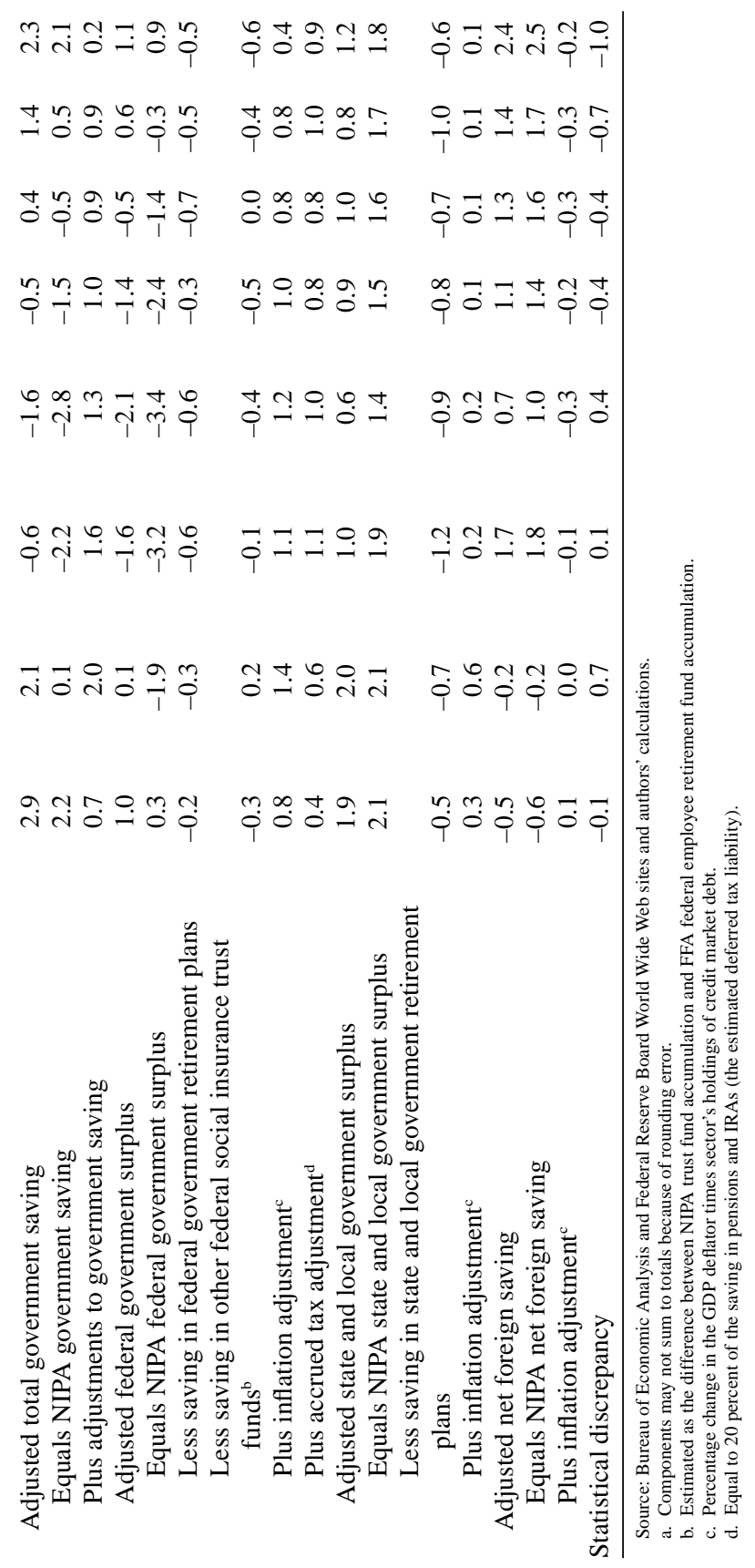


Taken together, the adjustments significantly alter the composition of the saving decline. For example, the adjusted personal and total private saving rates have fallen by less than the official NIPA measures suggest, both in the recent past and in the long run. Whereas NIPA personal saving fell by 3.1 percent of GDP in the 1990s, adjusted personal saving fell by only 0.8 percent of GDP. Relative to its levels in the 1970s and 1980s, NIPA personal saving in 1998 had fallen by almost 5 percent of GDP, and NIPA private saving by almost 4 percent of GDP. Adjusted private saving, however, fell by only about 2 percent of GDP.

Taken individually, the adjustments have a wide variety of effects. Investment in consumer durables was 2.3 percent of GDP in 1998 and increased by about 1 percent of GDP over the decade. We attribute this increase to the normal cyclical nature of durables investment. Adding investment in durables to NIPA net private domestic investment does not change long-run investment trends very much, however, because the fraction of GDP devoted to increasing the stock of durables in 1998 was close to its historical average.

Accumulation in government retirement accounts and trust funds is substantial, rising from about 1 percent of GDP in the 1960s to 1.7 percent in 1998. Shifting these funds from government to the personal sector alters saving levels in both sectors but does not change conclusions about the recent drop in personal saving, because government pension saving has been stable or even falling in the last decade. Adjusting for the accrual of taxes reduces personal saving by about 1 percent of GDP for the last thirty years but has not significantly altered the trend.

The inflation adjustment has a significant impact on reported saving rates. It reduces net saving of the two creditor sectors (households and foreigners) and raises net saving of the two borrowing sectors (government and corporations). The effect varies significantly over time because of changes in the underlying inflation rate. Much of the decline in nominal personal saving can be attributed to the decline in inflation. From the 1970s to 1995, the nominal personal saving rate fell by 3 percent of GDP, but disinflation accounts for five-sixths of that decline. Between 1995 and 1998 , the nominal personal saving rate fell by 2.3 percent of GDP, of which the reduction in inflation accounts for roughly 40 percent. Since the net inflation adjustment across sectors is zero, however, the inflation adjustments shift government and corporate saving in exactly the opposite direction. 
In summary, the NIPA adjustments made above raise the level of saving, reinforce the notion that saving has declined, and change somewhat the attribution of the source of the decline. In particular, official NIPA personal and private saving figures show larger declines than the adjusted measures do.

\section{Saving in the Flow of Funds Accounts}

Our second perspective on saving uses data on household balance sheets to examine how the composition of private and household saving has changed over time. We use the measure of household sector saving in the Federal Reserve Board's flow of funds accounts. ${ }^{15}$ The FFAs measure the value of wealth holdings and debt at discrete points in time and the active acquisition and disposition of assets and liabilities. The change in levels between discrete points in time is the sum of net acquisitions and revaluations. The FFA measure of saving is just the net acquisitions component of the change in the wealth-like the standard NIPA measure, the standard FFA measure of saving does not include capital gains.

The FFA measure of personal saving is intended to represent the same concept as the NIPA measure, except that accumulations in government pensions and net investment in consumer durables are attributed to household saving. In practical terms, however, the NIPAs and the FFAs use different data sources and different approaches to measuring saving, and these differences create statistical as well as conceptual discrepancies between the series. The statistical differences are generally less than 1 percent of income in absolute value.

Our results for the FFA saving rate are not strictly comparable to the NIPA saving rate measures reported above, nor are they intended to be. Our analysis of NIPA saving focused on how various adjustments altered the allocation of saving across sectors, and such an analysis requires a denominator (GDP) that includes all sectors. In contrast, our analysis of the FFA data focuses on the composition of private saving. Thus we use a measure of private sector net resources as the denominator for the FFA saving rates. The income measure-which we call expanded disposable income-is the sum of NIPA disposable income, net investment in gov-

15. See Wilson and others (1989) for a detailed description of the FFA data. 
ernment pensions, and corporate retained earnings, less the implied tax accruals on pensions.

Table 3 shows our estimates of aggregate, FFA-based saving rates. These rates reflect the decline in saving found in the NIPA data. FFA private saving fell from an average of about 15 percent of expanded disposable income in the 1980s to 9 or 10 percent in 1996-98. The equivalent measure of household saving, shown in the third line, fell from 12.2 percent of expanded disposable income in the 1980s to an average of under 5 percent in $1996-98 .{ }^{16}$

\section{Gross Saving and Borrowing}

Table 3 decomposes net saving into gross saving and gross borrowing and their components, in order to examine several portfolio issues. ${ }^{17}$ The main finding is that the long-run decline in FFA saving is largely associated with a reduction in gross saving and, within gross saving, the net acquisition of financial assets. Acquisition of such assets, net of tax accruals implicit in pension saving, fell from about 13 percent of GDP in the 1980s to 6 percent in 1996-98.

The quantitative importance of borrowing in recent saving trends depends on the time frame chosen. Over the course of the 1990s, the rise in private borrowing accounts for more than 100 percent of the decline in private saving. But comparing recent years with earlier decades suggests little change in borrowing rates. Borrowing rates in 1995-97 were somewhat lower than in the 1970s and 1980s, and the borrowing rate in 1998 was only about 1 percent of GDP higher. Even the 1998 value, however, may not suggest an important upsurge in borrowing. Borrowing tends to be procyclical, and the long economic expansion may be one factor driving up borrowing recently. Moreover, the 1998 data are preliminary and subject to revision.

Table 3 also provides information on borrowing relative to household investment in the tangible assets for which people seem most likely to take

16. For comparison purposes, the table also reports the standard FFA household saving rate, which uses NIPA disposable income as the denominator, in the last memorandum line. Our constructed household saving measure is slightly lower than the FFA household saving measure in all periods.

17. We do not provide a measure of gross corporate borrowing, because the corporate sector in the FFAs is not fully separated from other businesses. Whereas nonfinancial businesses are separated by corporate status, financial businesses are not. 


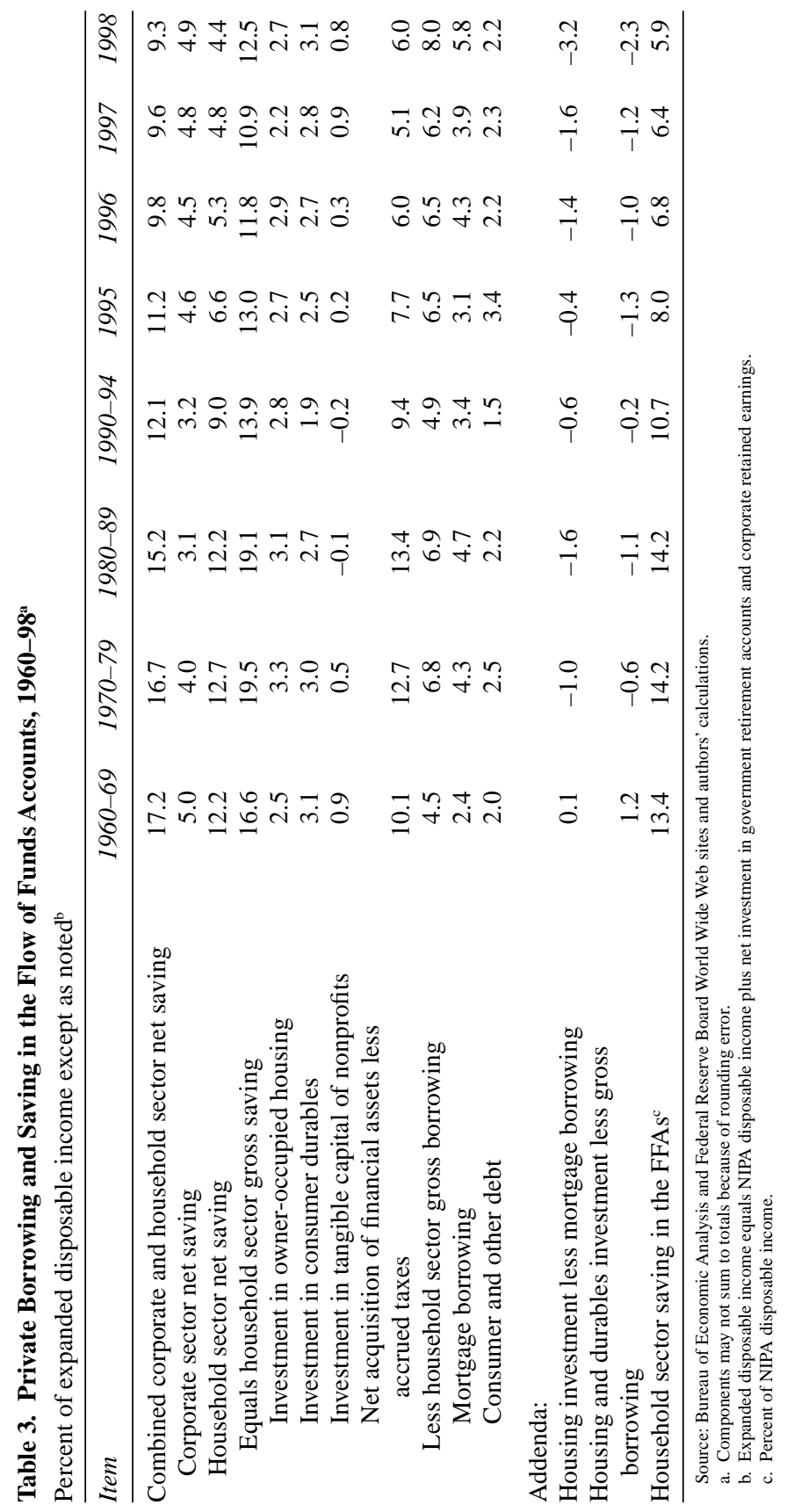


out loans. The household sector has a long history of borrowing against its physical capital. Investment in housing less mortgage debt has been negative during the last thirty years, including during the inflationary years of the 1970s when real estate boomed. However, the interpretation of this variable changes after 1986, because the Tax Reform Act of 1986 eliminated the deductibility of nonmortgage interest and encouraged a shift toward mortgage debt. ${ }^{18}$ Examining household investment in durables and housing, however, reveals roughly the same trend: borrowing exceeded tangible investment throughout the late 1990s, but the rates (except in 1998) are not substantially different from previous time periods. Thus the data do not suggest that increased borrowing against housing and other tangible wealth has led to a decline in saving. But interpretations should be cautious: in the 1970s real house prices rose rapidly, whereas in the 1980s and 1990s this appreciation has slowed. ${ }^{19}$

\section{Saving in Retirement and Nonretirement Accounts}

Our second balance-sheet saving decomposition, shown in table 4, focuses on the distinction between qualified retirement saving vehiclessuch as pensions, 401(k)s, IRAs, and Keoghs - and other saving. ${ }^{20}$ Pension saving is measured explicitly in the FFAs, and we use data from a variety of sources to estimate IRA saving (as discussed in appendix A).

Whereas table 3 indicated that a decline in net acquisitions of financial assets accounts for the decline in saving, table 4 suggests that the source can be pinpointed even more closely: almost all of the decline occurred in saving outside of qualified retirement vehicles. For example, personal saving fell by almost 7 percent of expanded disposable income from the average of the 1970-79 and 1980-89 periods, as did households' net acquisition of nonretirement financial assets. In contrast, saving in retirement vehicles was roughly the same in 1998 as its average in the 1970s and 1980s, gross borrowing rose by 1 percent of expanded disposable income, and corporate retained earnings rose somewhat.

Within retirement saving, private and government pensions have maintained relatively constant shares of GDP over the last thirty years. Nor

18. Maki (1995).

19. Steuerle (1990) examines similar issues from an earlier vantage point.

20. The latter category could, of course, include other assets that households view as saving for retirement. 


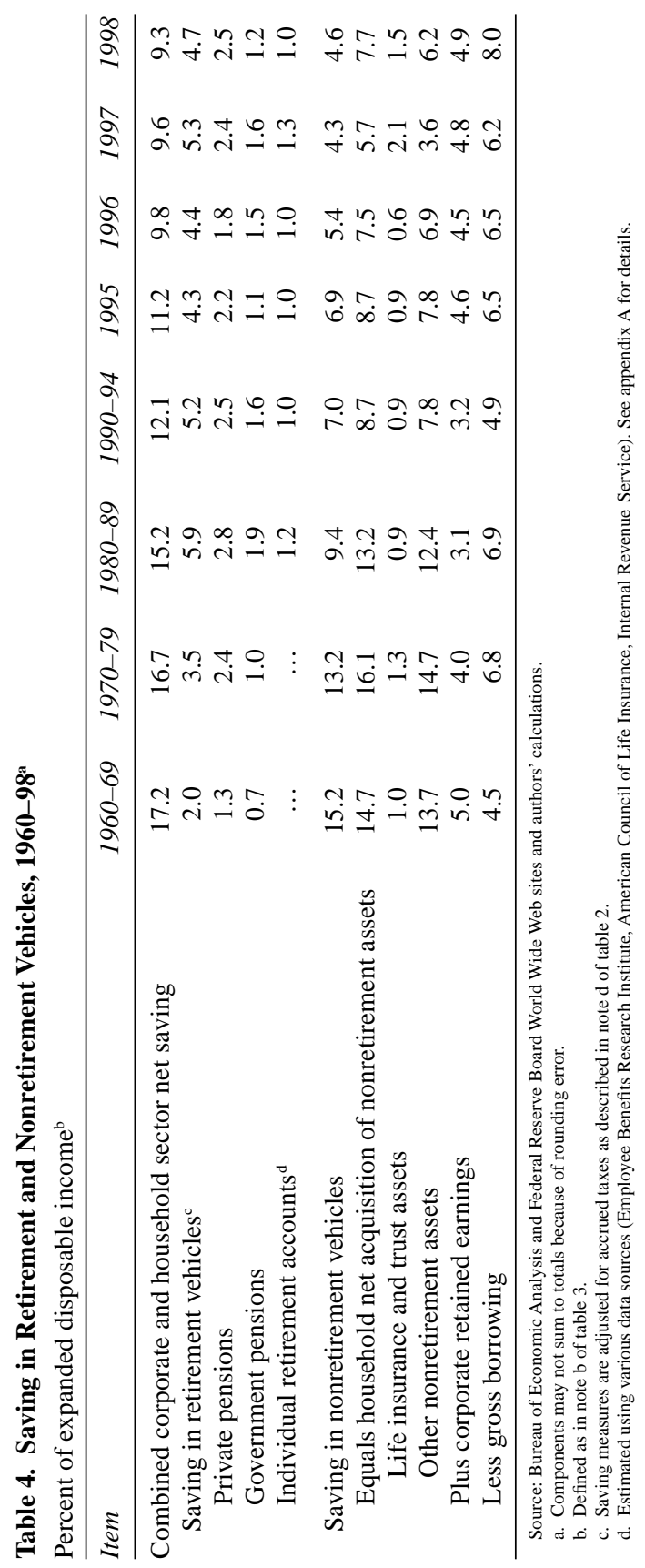


has IRA saving fallen, even though restrictions on the deductibility of IRA contributions after 1986 severely curtailed new contributions. The strength of IRA saving in the late 1980s and 1990s is attributable to a high rate of rollovers from pensions to IRAs, which underscores the importance of examining all retirement saving vehicles simultaneously. ${ }^{21}$

\section{Capital Gains}

The FFA analysis, like the NIPA results, shows that plausible adjustments and decompositions of measured saving rates can generate new insights on saving behavior. However, none of the estimates above include capital gains. Given the massive runup in stock market values in recent years, the magnitude and interpretation of such gains are important features of wealth accumulation. Our third perspective therefore incorporates capital gains into saving rate measures.

\section{Sources of Changes in Wealth}

Table 5 compares the magnitude of capital gains and measured FFA saving over the past forty years. The calculations use the same denominator, expanded disposable income, as in tables 3 and 4 . Thus the household sector net saving rate in table 5 excludes capital gains and is the same as the value in the third line of table 3.

Table 5 demonstrates several key points. First, capital gains have dominated measured saving as a source of wealth change in the last forty years, except during the 1960s and 1990-94. Even in those periods, however, capital gains were as large as measured saving.

Second, the overall rate of capital gains since 1995 is large relative to earlier years and will prove even larger when the decline in inflation is taken into consideration below. Since 1995, capital gains have accounted for over 80 percent of the gains in household sector net worth. In 1997 and 1998, capital gains were approximately ten times measured saving.

Third, the composition of capital gains has changed over time. In the 1970s and 1980s, tangible capital accounted for about half of all capital gains. In the 1990s, however, financial assets have accounted for almost all 


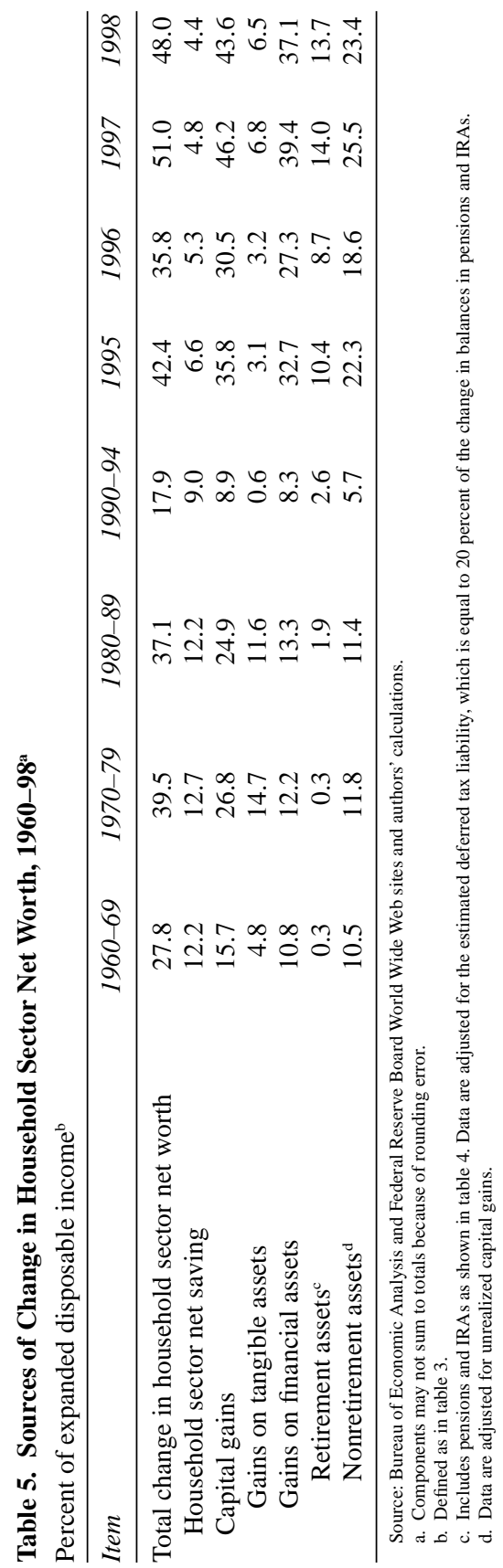


of the gains. Capital gains on pension assets alone have equaled about 10 percent of income over the past four years.

It is important to note that our measure of aggregate capital gains does not-and need not-conform closely to changes in aggregate stock market indices over the relevant periods. For example, whereas the S\&P 500 rose by 70 percent between 1959 and 1969, by only 5 percent between 1969 and 1979, and by 213 percent between 1979 and $1989,{ }^{22}$ our measure reports capital gains of roughly the same percentage of expanded disposable income in all three decades. The main source of the difference is that our measure includes capital gains not only on publicly held corporations-which are captured in stock market returns-but also on privately held corporations and on noncorporate business assets. For these entities, the change in their value in the FFAs is calculated by adjusting estimates of the land and physical capital they own by prices of land and physical capital. These differences are examined in detail in appendix B.

Figure 1 plots the data in table 5 on an annual basis. The data show substantial year-to-year variation in capital gains. In the past, large accruals of capital gains, such as have occurred in recent years, have proved to be a temporary phenomenon.

\section{Gains-Inclusive Saving Rates}

To examine saving rates that include capital gains in an internally consistent manner, we add capital gains to both the numerator and the denominator of the FFA saving rate used in tables 3 and 4. (Equivalently, we add capital gains to the denominator of the values reported in the top line of table 5, which already includes capital gains in the numerator.) This makes the numerator equal to the change in household sector net worth and the denominator equal to expanded disposable income plus capital gains. We refer to this income measure as gains-inclusive income.

The top line of table 6 reports the change in household sector net worth as a percentage of gains-inclusive income; the results differ from the rates of wealth change in table 5 only in that capital gains are now included in the denominator. The saving rates in table 6 are noticeably lower than the values in table 5, because including capital gains raises the denominator significantly, especially in recent years. Nevertheless, the late 1990s still stand out as a period of very rapid wealth growth. The gains-inclusive

22. Economic Report of the President, 1999, table B-95. 
Figure 1. Sources of Change in Household Sector Net Worth, 1960-98

Percent of expanded disposable income

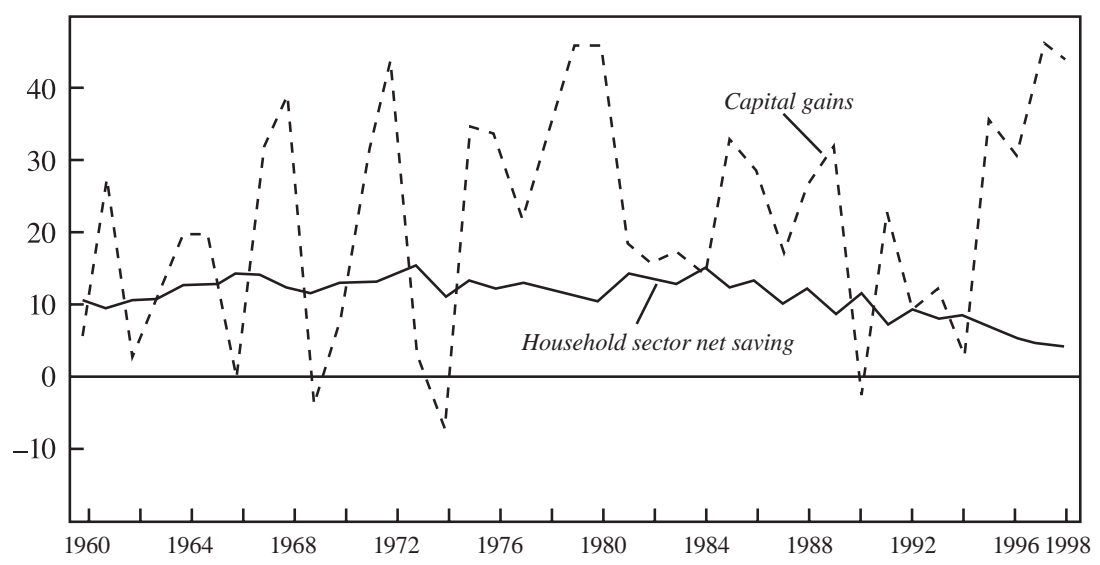

Source: Bureau of Economic Analysis and Federal Reserve Board World Wide Web sites and authors' calculations.

a. Both series are adjusted for accrued tax liabilities on retirement account saving and unrealized capital gains. Expanded disposable income is defined as in table 3 .

saving rate has averaged around 35 percent since 1995 . This greatly exceeds the rates attained in the 1960s and the early 1990s and is approximately the same as those in the 1970s and 1980s.

Because these results are in nominal terms, we compute a measure of real gains equal to nominal gains less the product of the inflation rate (as measured by the GDP deflator) and beginning-of-period net worth. We then calculate the real gains-inclusive saving rate with real instead of nominal gains in both the numerator and the denominator.

Because of the sharp drop in inflation since the late 1970s, adjusting for inflation dramatically changes the results. The increase in household net worth falls by 20 percent of gains-inclusive income in the 1970s, from 33 percent to 13 percent. In the 1960s, 1980s, and 1990-94, the annual increase in household net worth falls by about 10 percent of gainsinclusive income. In contrast, the inflation adjustment for the late 1990s is small. Thus real gains-inclusive saving rates in the late 1990s are higher than at any point in the past forty years, and the inclusion of capital gains in a saving rate measure greatly amplifies the impact of correcting reported saving rates for inflation.

The inclusion of capital gains highlights the fact that part of the measured increase in household sector wealth is an accrued tax liability of 


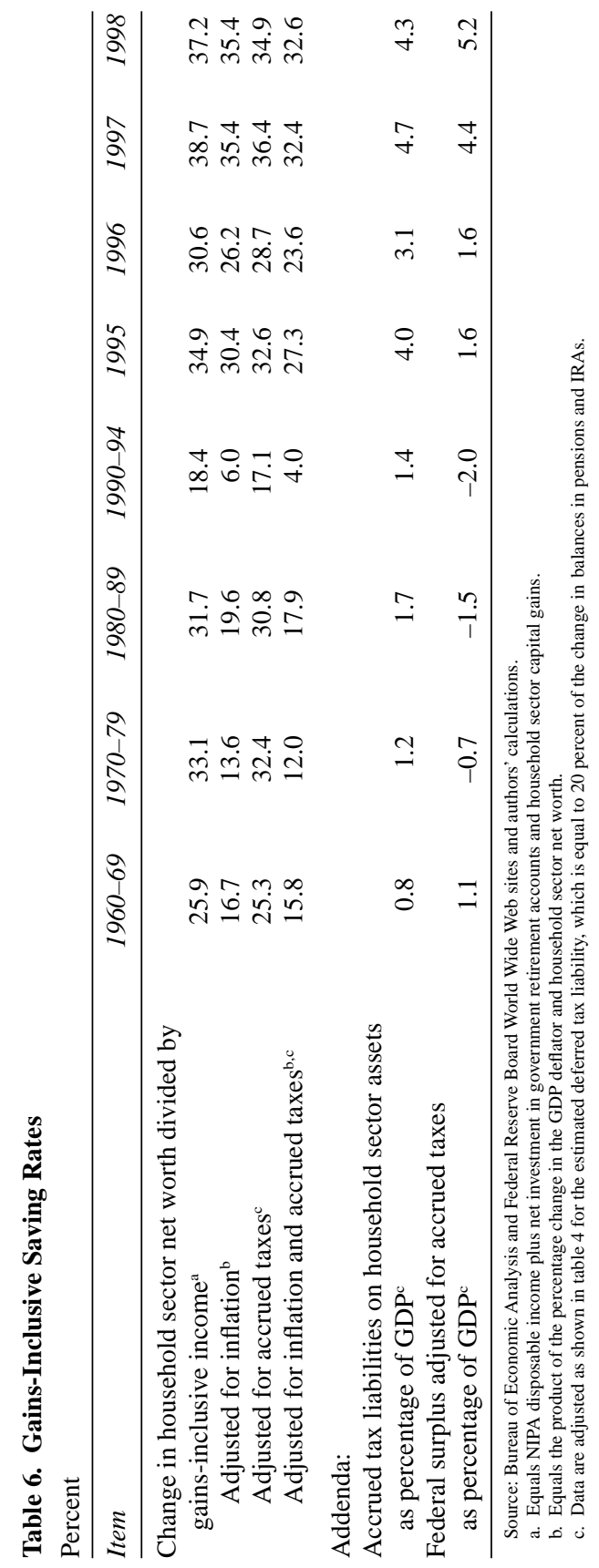


that sector, because taxes may be due on capital gains when they are realized. In the analysis in tables 1 through 4 we adjusted pension saving (defined to exclude capital gains) for tax accruals, using 20 percent as an estimated tax rate. Here we continue to adjust traditionally measured pension saving by 20 percent, but we also adjust accrued capital gains on pensions by 20 percent and accrued capital gains on taxable assets by 10 percent (the latter to reflect accepted rules of thumb in public finance). As before, we do not present these as precise estimates; our goal is rather to determine whether accounting for tax accrual significantly affects the trends in the data.

We adjust both the numerator and the denominator of the saving rate calculations for tax accruals. The results in the third line of table 6 show that, before adjusting for inflation, the tax accrual adjustment averages about 1 percent of gains-inclusive income in the 1960s and 1970s, rising to about 2.5 percent in the $1990 \mathrm{~s}$.

When both the inflation and tax accrual adjustments are applied in table 6 , the effect of the latter on the time path of estimated wealth accumulation rates is slightly amplified. The accrued tax effect is fairly small in the 1960s and 1970s, lowering the rate of wealth accumulation by about 1 to 2 percent of gains-inclusive income. By the late 1990s, when pensions and capital gains are booming, the adjustment is about 3 percent of gainsinclusive income.

Figure 2 shows gains-inclusive saving rates on an annual basis. The figure reflects the large year-to-year variation in capital gains shown in figure 1 , but it also clearly shows the joint effects of adjusting for inflation and tax accruals. The adjusted figures for household wealth accumulation are larger, relative to gains-inclusive income, than at any time in the past forty years.

Interestingly, the adjustment for tax accruals has a significant impact on the time path of the federal budget surplus, measured as a proportion of GDP. ${ }^{23}$ Accruing tax liabilities have been approximately 4 percent of GDP in recent years. Much of this is due to retirement accounts. Accrued liabilities on pensions and IRAs alone have risen by $\$ 2$ trillion since 1980 (because pension and IRA balances have grown by $\$ 10$ trillion); this is about half the size of the outstanding federal debt. Adjustments for tax

23. The equivalent denominator adjustment for the federal government would be to add accrued tax liabilities to GDP when computing the government saving rate. 
Figure 2. Gains-Inclusive Saving Rates, 1960-98

Percent of gains-inclusive income

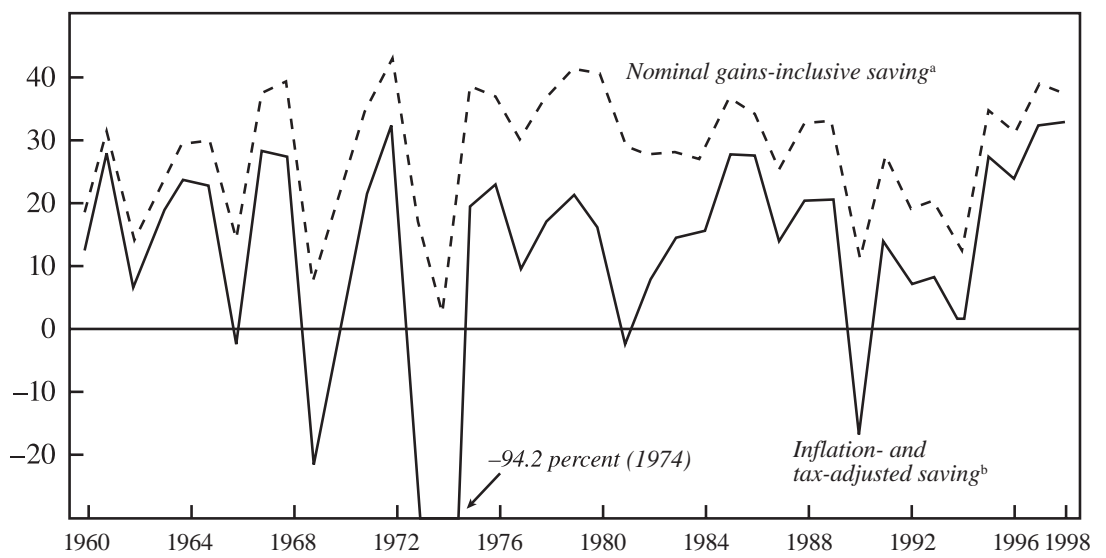

Source: Bureau of Economic Analysis and Federal Reserve Board World Wide Web sites and authors' calculations.

a. Change in household sector net worth divided by gains-inclusive income. Gains-inclusive income is NIPA disposable income plus net investment in government retirement accounts and household sector capital gains (see first line of table 6).

b. Inflation- and tax-adjusted saving rate starts with the nominal gains-inclusive saving rate, then subtracts inflation losses on household sector net worth and accrued tax liability on pension accumulations and unrealized capital gains from both the numerator and the denominator (see fourth line of table 6).

accruals, however, do not change the overall long-term fiscal stance of the federal government. That is, attributing the tax accruals to federal resources when the accruals occur implies that they cannot be attributed again in the future, when the taxes are paid. Nevertheless, examining the time path of tax accruals suggests that fiscal policy has not been as profligate as it may have first appeared in the 1980s and early 1990s. It also suggests that a significant portion of future revenues are attributable to realized capital gains, pension withdrawals, and other deferred incomes that represent repayment of tax loans made by the government.

\section{Should Capital Gains Be Included in Measures of Saving?}

The results above show that interpretations of recent saving behavior hinge crucially on whether capital gains are included as saving. Here we discuss some of the major arguments for and against including capital gains as saving. ${ }^{24}$

24. For related analyses see Auerbach (1985), Summers and Carroll (1987), Bradford (1990, 1991), and Hendershott and Peek (1989). 
Whether capital gains should be included as saving depends to some extent on the issue being examined. For example, a household preparing for retirement should include capital gains in its measure of what its members have saved, since capital gains can be consumed in retirement just as easily as interest and dividend earnings.

At an aggregate level, however, the issue is more complex. Auerbach notes that if saving is the creation of resources today in order to consume more tomorrow, then whether capital gains should be included as saving depends on the source of the gain. ${ }^{25}$ If the underlying asset has become more productive, the capital gain should be thought of as saving. However, if it results from a shift in tastes, the capital gain has not contributed anything to increasing future income or production and so should not be considered saving.

Auerbach's analysis, which is useful for tracing out a variety of effects, starts with a closed economy. For example, a decline in the value of a machine due to a fall in its productivity should be counted as a decline in saving. However, a decline in its value due to the invention of a new, better machine should not count as a fall in saving, since there is no implied decline in future production or consumption.

Auerbach also provides an interesting example regarding the role of tastes in determining capital gains, still in a closed economy. Suppose each middle-aged generation owns land, which is fixed in quality and quantity and is the only store of value, and sells it to the next generation to finance its own retirement. A change in the price of land that occurs because one generation has a different discount rate than all of the others will introduce capital gains but no increase in future consumption. Thus, in this example, real revaluations of assets that occur because of changes in time preference rates or risk premiums should not be reflected in saving.

This implies that even if capital gains increase an individual's or a cohort's wealth, they may also impose costs on other individuals or cohorts and therefore may not increase aggregate wealth. That is, just because it is appropriate to include capital gains in measuring the resources of an individual or cohort does not automatically imply that it is appropriate to include such gains in measuring aggregate saving. ${ }^{26}$

26. Schultze (1990) provides a related example based on the value of taxicab medallions. 
The implications of Auerbach's example, however, may be different in an open economy. Changes in the price of a domestic asset that are due to changes in domestic tastes cannot raise future national consumption in a closed economy. However, in an open economy, asset price changes due to changes in domestic tastes could raise future national consumption to the extent that the gains expand U.S. consumers' and firms' ability to purchase goods or services from other countries. Of course, not all domestic capital gains will expand U.S. nationals' ability to command foreign resources: there may be equivalent capital gains in other countries, the domestic capital gains may accrue to foreigners, and exchange rate adjustments would need to be taken into account. Nevertheless, to the extent that any domestic capital gain raises the country's ability to purchase resources from other countries, that gain should count as an addition to national saving-even if it is due to changes in tastes and is therefore not an increase in world saving.

That is, the role of an individual country in a world economy is much like that of an individual or a cohort in a closed economy. In a closed economy, a capital gain due to shifts in tastes should count as saving for the individual receiving it, even if it does not add to saving at an aggregate level. Likewise, in an open economy, a capital gain due to shifts in tastes should count as saving for the country receiving it - to the extent that it raises the country's future consumption possibilities-even if it is not an addition to saving at the world level.

In practice, determining which capital gains fall in which category is difficult. Bradford, for example, acknowledges that changes in discount rates could cause changes in market values, and he notes several other problems with using market values as indicators of saving, but he concludes nevertheless that the change in market value remains a more useful saving concept than NIPA measures. ${ }^{27}$ Schultze suggests that most capital gains have little to do with increases in future production or income and so should not be counted as saving, but he implicitly acknowledges that capital gains that do raise future production and income should be included as saving. ${ }^{28}$

More recently, Glassman and Hassett argue that the recent runup in stock prices is due in large part to the decline of the equity risk premium. ${ }^{29}$

27. Bradford (1990, 1991).

28. Schultze (1990).

29. Glassman and Hassett (1999). 
They point out that the growth of dividends or earnings per share has not changed much in recent years relative to historical norms, but that earnings and dividend yields have plummeted. They argue that this pattern is more likely to be the result of changes in investors' attitudes toward risk than of massive infusions of new (intangible) capital, because a large amount of new capital would normally be reflected in current and medium-run earnings forecasts, and this does not appear to be the case. In this view, the runup in stock prices should only be considered an increase in national saving to the extent that it has increased Americans' ability to purchase goods and services from abroad.

Hall, however, offers an opposing view, namely, that accruing capital gains on corporate stock can be interpreted as increases in the quantity of capital under certain conditions - the absence of monopoly rents, scarcity rents, and adjustment costs. ${ }^{30} \mathrm{He}$ presents evidence that the value of aggregate corporate securities behaves over time essentially as one would expect if the value of securities reflected the quantity of capital. These results suggest that recent capital gains should be included in saving.

\section{Concluding Remarks}

This paper has evaluated official measures of the saving rate in light of the recent decline of NIPA personal saving to effectively zero. We find, as do others, that official saving measures are not representative of basic economic concepts and that various adjusted measures of saving have moved in markedly different directions over the past two decades.

In particular, whereas NIPA personal saving declined from about 5 percent of GDP in the 1970s and 1980s to less than 0.5 percent in 1998, an alternative measure that adjusts personal saving for durables, retirement accounts, inflation, and tax accruals and integrates personal and business saving fell only from about 9 percent of GDP in the 1970s and 1980s to 7 percent in 1998. By this measure, which we would claim is closer to an economic concept of saving, the decline is much smaller, and the current level of saving much higher, than under the conventional measure.

Adjusted FFA saving data show a similar decline. They also show that borrowing is not significantly out of line with past years and that the vast

30. Hall (1999). 
portion of the decline is concentrated in net acquisitions of nonretirement assets.

Adding capital gains fundamentally changes recent trends. If all capital gains are included, the current adjusted household saving rate is the highest in at least the last forty years, despite a personal saving rate of zero. However, it remains controversial whether it is appropriate to include capital gains in general, and the recent capital gains in particular, in saving.

Our findings suggest that, in principle, all discussions of whether saving has risen or fallen, and by how much, need to be qualified by the concept and measure of saving employed. In practice, this distinction appears to be crucial when considering data over the recent past. However, as Eisner noted in a similar exercise, "There is nothing sacrosanct about any of the time series presented in this paper." ${ }^{31}$ In particular, other items could be added to the definitions of saving or investment used in the present paper. Intangible capital may be growing rapidly, but these expenditures are not treated currently as saving or investment. ${ }^{32}$ Accumulation and decumulation of human capital share many of the same properties as accumulation and decumulation of physical or financial capital..$^{33}$ The discovery and development of natural resources clearly add to a nation's capital stock. ${ }^{34}$ Tangible government assets provide services and income flows just as comparable private assets do. ${ }^{35}$ The findings could also be extended to examine different measures of resources available to consumers. Kotlikoff and Bradford, for example, advocate the use of a measure that includes net national product plus consumption of durables and government tangible assets less government purchases of goods and services and capital investment. ${ }^{36}$ Gokhale, Kotlikoff, and Sabelhaus construct comprehensive estimates of all expected government benefits and taxes of the household sector and examine the changes in those expected values over time. ${ }^{37}$

We believe that the appropriate measure of saving will ultimately be a judgment call and will depend on the question being asked. But develop-

\section{Eisner (1991).}

32. Hall (1999); Blair and Kochan (1999).

33. Auerbach (1985); Eisner (1988); Jorgenson and Fraumeni (1989); Rosen (1989).

34. Nordhaus (1995).

35. Boskin (1986); Eisner (1988).

36. Kotlikoff (1989); Bradford (1990).

37. Gokhale, Kotlikoff, and Sabelhaus (1996). 
ing empirically comprehensive and theoretically consistent measures of saving would clearly be helpful. It would provide saving data that correspond more closely to the concept of saving employed in theoretical models. This would allow more informative tests of theory, better comparisons of saving over time and across countries with different institutional patterns, ${ }^{38}$ and greater understanding of the effects that policies that encourage one type of saving may have on other forms of saving. These issues are well beyond the scope of this paper but represent interesting avenues for future research.

APPENDIX A

\section{Estimates of IRA Saving}

To CALCULATE IRA saving and capital gains on IRAs, we use data from the Employee Benefits Research Institute (EBRI), the American Council of Life Insurance (ACLI), and tax returns. ${ }^{39}$

There are two ways to construct saving measures for pensions or IRAs. One is as the sum of employer and employee contributions, interest earnings, and dividend earnings, less benefits paid—-the FFA calls this "net acquisition" of financial assets. This net saving flow is conceptually identical to the second measure, which is calculated as changes in pension fund balances less capital gains.

We use both approaches to construct estimates of IRA saving. Using EBRI data on IRA balances at financial institutions, we subtract IRA balances held at life insurance companies using ACLI data, because those balances are already counted as pensions in the FFAs. We also use data on contributions to and withdrawals from IRAs, as reported on tax returns, and an estimate of interest and dividends paid on IRAs from unpublished NIPA sources. We do not have direct data on rollovers from pensions to IRAs, but we proxy those flows using the gap between gross and taxable pension distributions as reported by taxpayers on their 1040 forms. ${ }^{40}$

38. Eisner (1988).

39. See Fronstin (1998) and American Council of Life Insurance (1998) for descriptions of the data.

40. The rollover estimate is described in detail in Sabelhaus (1998). A direct estimate of rollovers, based on linked form 1040 and IRA and pension information returns in Sabelhaus and Weiner (1999), confirms this approach. 
Given the data on IRAs from many sources, it is instructive to see how well the flows and balances fit together. The missing link is capital gains: we estimate these gains by applying the change in the S\&P 500 to IRAs held at brokerage institutions and mutual funds. We then compute the IRA flow discrepancy as the change in balances less estimated gains, contributions, rollovers, and interest and dividend earnings, plus withdrawals. The pieces of the puzzle fit together quite well; on a percentage basis the discrepancy is quite small. ${ }^{41}$ Our measure of IRA saving is then the change in IRA balances less estimated capital gains.

\section{APPENDIX B}

\section{Decomposition of Capital Gains}

THIS APPENDIX SHOWs how capital gains on financial assets in the flow of funds accounts have varied across categories of assets and across time. Changes across time do not necessarily track broad movements in stockprice indices because of the way gains are computed and because traded equities are only one component of total financial assets. Here we spell out more clearly how gains are computed in the FFAs, and we separate gains on traded equities from other types of gains to show the relative magnitudes.

Table B1 shows balances and sources of change in four broad categories of financial assets in each of the last four decades. Total financial assets are divided among directly held corporate equities (including mutual funds), pension funds (which hold a mix of stocks and bonds), equity in noncorporate businesses, and other financial assets. Notice that even the "other" category will include some stock holdings, because it includes, for example, personal trusts.

Capital gains are not measured directly in the FFAs; rather, they are residuals, which reconcile the beginning and ending balances after accounting for the two other sources of change. The household sector begins each period with holdings in each of the four categories and then

41. Sabelhaus (1998). It is important to note that all of the IRA data series end before 1998, and we extend the series through the end of 1998 using the methodology described in Sabelhaus (1998). 


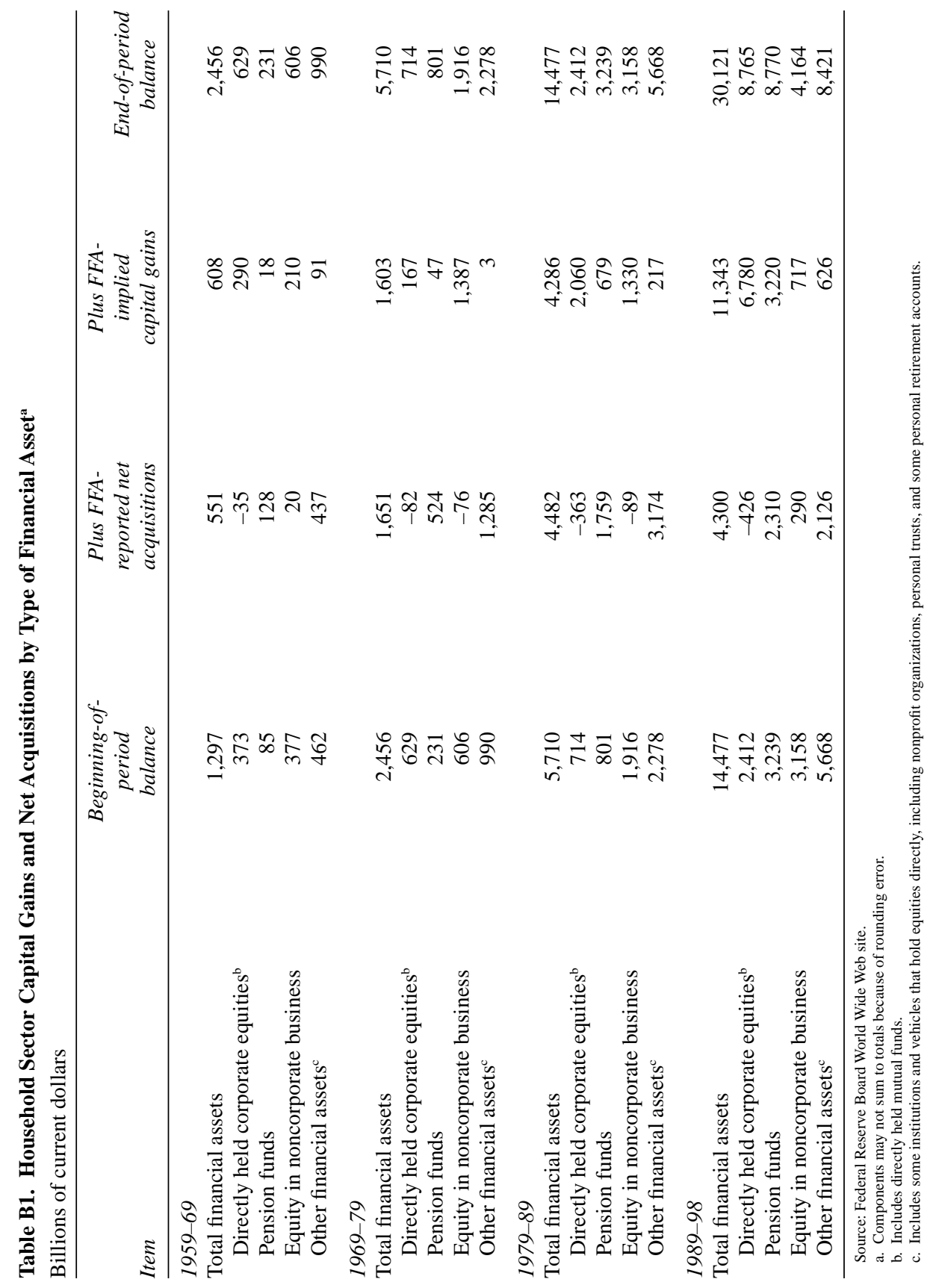


buys or sells units of assets in each category during the period. At the end of the period there is a new stock of holdings, which equals the beginning stock plus net purchases (or "net acquisitions" in FFA terminology) plus capital gains ("asset revaluations" in the FFAs). Since the beginning and ending stocks and net acquisitions are measured directly, the revaluations estimate is the balancing item.

Thus, in each line of table B1, the third column is solved for given the other columns, which are input directly from the FFAs. Certain types of assets within categories are not revalued; in particular, bonds are always measured at par value, and therefore no gains are recorded. However, there are measured gains in all four categories because, as noted, there is some level of equity holding in each of the four-even "other" financial assets.

The relationship between aggregate stock market indices and overall capital gains is clear in table B1. For example, in each of the last two decades, gains on directly held corporate equities nearly tripled the initial value of household sector holdings in that category, and thus the value of these holdings grew rapidly even though households were net sellers of equities. Pension funds also experienced gains, but the fact that equities make up only part of their asset holdings lowered the category's percentage growth. Gains were only a small part of the story for growth in other assets.

In the 1970s, however, gains on equities were much smaller, which is consistent with the lack of growth in aggregate stock-price indices during that decade. On the other hand, noncorporate businesses are seen to have reaped significant gains in the 1970s. Unlike for publicly traded equities, no market valuation data are available for unincorporated or closely held businesses, and therefore the FFAs revalue their assets directly. For these entities, the change in value in the FFAs is calculated by adjusting estimates of the land and physical capital they own by prices of land and physical capital. Thus, just as tangible assets such as land and housing held directly by the household sector were revalued as inflation raged in the 1970 s, so, too, were the tangible assets of noncorporate businesses. Indeed, revaluation of noncorporate business equity accounts for almost 90 percent of the nominal revaluation of financial assets during the 1970s. 


\section{Comment and Discussion}

Robert E. Hall: William Gale and John Sabelhaus take us on a fascinating tour of data on U.S. financial markets, organized as a discussion of flows of saving. I belong firmly to the school of thought that considers consumption and output as fundamental variables and income and saving as constructs derived from those fundamentals. This school is associated with Irving Fisher, Milton Friedman, Franco Modigliani, and essentially all modern research in general-equilibrium macroeconomics. But I will not go nearly so far as to say that data on saving are uninformative. This paper shows quite the opposite. Models based on fundamentals have implications for saving and income flows, and data on these flows can be studied fruitfully to check ideas about the models.

The national income accounts distinguish between business and personal saving. I agree with the authors' statement that the line between them is "thin and somewhat arbitrary." Their findings support adding the two together to arrive at private saving, which is the way I will proceed. Of course, the view that people treat businesses as extensions of themselves is a close relative of the more controversial proposition that they treat the government as an extension of themselves as well. Again, the paper supports this proposition, but I will not collapse the government into the private economy. I will consider private, government, and foreign saving.

Table 1 below summarizes the basic findings of the paper about these saving flows in the NIPA data. The table reports the authors' adjusted data, taking account of the NIPAs' failure to state interest flows correctly under inflation, counting consumer durables accumulation as investment, and putting all retirement programs on an equal footing. I concentrate on a 
Table 1. Change in Adjusted Saving Rates by Type, 1980s and 1998

Percent of GDP

\begin{tabular}{lrrr}
\hline Type of saving & $1980 s$ & 1998 & Change \\
\hline Private & 8.6 & 6.9 & -1.7 \\
Government & -0.6 & 2.3 & 2.9 \\
Foreign & 1.7 & 2.4 & 0.7 \\
Total $^{\mathrm{a}}$ & 9.7 & 11.6 & 1.9 \\
\hline
\end{tabular}

Source: Gale and Sabelhaus, this volume, table 2.

a. Sum of the components of saving as reported by the authors. It differs from their "Adjusted sources of funds for net domestic investment" by the statistical discrepancy.

comparison of the 1980s with 1998, the year of the extreme emergency in personal saving.

By far the most important fact revealed in the table is the swing in government saving. Government—federal, state, and local—went from being a user of saving in the aggregate to being a contributor of saving. Private saving fell to offset this change in the government's role in credit flows. Almost any reasonable general-equilibrium macroeconomic model would have predicted this offset, even if it did not imply full Ricardian neutrality.

The data for this period show a very modest increase in total saving. Strict neutrality would have total saving unresponsive to changes in government saving, but there were other changes between the 1980s and 1998 that could account for the change.

Any reasonable model would have foreign saving move in the opposite direction from government saving - this was the idea of the twin deficits of the mid-1980s. But it did not happen in the 1990s. The trade deficit widened despite the huge swing in government saving. The unique position of the thriving U.S. economy in a weak world economy in 1998 presumably accounts for this. Again, the big change in government saving is not the only difference between the 1980s and 1998.

At the same time that the government was moving from a user of saving to a supplier, there was a huge increase in consumption as a fraction of GDP over the 1980s and 1990s. It is important to note that the mechanism of rising consumption is logically separate from the one connecting government saving to total saving. Consumption grew as a mirror image of a huge decline in government purchases of goods and services. The shift in the relation between disposable income and consumption is only a small part of 
the story of increased consumption in relation to GDP. Rather, the government has shifted from collecting taxes to pay for goods and services to collecting taxes to pay for transfers. Resources freed as a result of a huge shrinkage in government purchases - mainly in military spending — have been funneled into consumption. This would have happened even if there had been no change in government saving and no change in private saving.

The paper shows that there is a lot to learn from the FFA data as well. Table 2 below shows data extracted from tables 3 and 4 in the Gale and Sabelhaus paper, boiled down to reveal the most interesting findings. The top line shows households' acquisitions of physical capital: houses and durable goods. This type of investment rose slightly from the 1980s to 1998 , not surprisingly given that 1998 was an incredible boom year. The second line shows a modest decline in net contributions to retirement plans. The real surprise is in the third line: households became major net sellers of nonretirement financial wealth in 1998. This is a combination of borrowing more and selling more equity.

One factor in the huge swing in household asset transactions was increases in housing values. As houses change hands, the purchasers take out larger mortgages than the sellers had. As the paper shows, net mortgage borrowing exceeded investment in new houses in both the 1980s and 1998. But the stock market is the centerpiece of the story of net sales of nonretirement assets. Despite the net sales, the stock market wealth of U.S. households rose astronomically over the period. Presumably most of the net asset sales from households were to foreigners, either through sales of securities to them or through borrowing from them. The principal alternative way that net sales could have occurred is through repurchases of shares by corporations.

Table 2. Changes in Household Sector Net Saving by Type, 1980s and 1998

Percent of expanded disposable income

\begin{tabular}{lccc}
\hline Type of saving & $1980 \mathrm{~s}$ & 1998 & Change \\
\hline Investment $^{\mathrm{a}}$ & 5.8 & 5.8 & 0.0 \\
Retirement $^{\mathrm{b}}$ & 5.9 & 4.7 & -1.2 \\
Other financial $^{\mathrm{c}}$ & 0.5 & -6.1 & -6.6 \\
Total & 12.2 & 4.4 & -7.8 \\
\hline
\end{tabular}

Source: Gale and Sabelhaus, this volume, tables 3 and 4.

a. Sum of owner-occupied housing and consumer durables.

b. Saving in retirement vehicles by corporations and households.

c. Calculated as a residual. 
The third topic explored in the paper is how and whether to bring capital gains into measures of saving and income. Again, the authors make important adjustments to the official data. Table 3 compares their adjusted data with the data without adjustment for capital gains. The authors perform this exercise at the level of the household, and thus they sidestep a tricky issue that would arise if they tried to include capital gains in total saving. The capital gain that occurs when a firm reinvests profit in physical capital is already included in NIPA saving to the extent of the capital itself. Only the excess of the capital gain over the recorded saving of the corporation should be added to saving and income. But because household flows do not include business saving, this problem does not arise in the paper.

The table shows the startling results of adding capital gains to the saving data. Instead of a decline in household saving, 1998 records a huge increase over the 1980s. No wonder households were shedding some of their financial assets-the ones they kept had grown so much in value!

The paper only hints at an analysis of whether or not capital gains should be included. It identifies two polar positions. One is associated with Alan Auerbach, who noted that capital gains on land-an unproduced factor of production whose value would rise with a decline in the rate of time preference-are not income in any useful sense. ${ }^{1}$

The Auerbach position is supported by John Campbell and Robert Shiller. ${ }^{2}$ Their position is that the ratio of stock prices to dividends is at an abnormal high, consistent with the possibility that stock prices will fall. As a result, the anticipated return could be low or even negative. In this view it would be silly to include the capital gains of the past seventeen years in income and saving. If capital losses should occur as a result of the price-dividend ratio returning to normal, these would have to be deducted from income and saving in future years, which would make the data appear ridiculous.

The other position, associated with Martin Baily and David Bradford, links capital gains to firms' unmeasured investments in productive assets, such as new technology. ${ }^{3}$ In that case, capital gains in excess of measured business saving reveal the volume of those investments. Capital gains could logically be added to income and saving in this case. My own recent work, as Gale and Sabelhaus note, is sympathetic to this position.

1. Auerbach (1985).

2. Campbell and Shiller (1998).

3. Baily (1981); Bradford (1990, 1991). 
Table 3. Saving in the Flow of Funds Accounts With and Without Adjustment for Capital Gains

\begin{tabular}{|c|c|c|c|}
\hline Measure of saving & $1980 s$ & 1998 & Change \\
\hline $\begin{array}{l}\text { Without capital gains (percent of } \\
\text { expanded disposable income) }\end{array}$ & 12.2 & 4.4 & -7.8 \\
\hline $\begin{array}{l}\text { With capital gains (percent of } \\
\text { gains-inclusive income) }\end{array}$ & 17.9 & 32.6 & 14.7 \\
\hline
\end{tabular}

Source: Gale and Sabelhaus, this volume, tables 3 and 6.

a. After adjustment for inflation and accrued taxes.

The second polar position has recently been advocated forcefully by Greenwood and Jovanovic. ${ }^{4}$ They report interesting evidence in support of the idea that information technology (IT) is the driving force of large future increases in productivity. A basic premise of their analysis is that an IT revolution began around 1970. Its immediate effect was to lower the value of firms with pre-IT technology-hence the sharp drop in the stock market in relation to GDP in the early 1970s. At that time, according to their scenario, it became known to investors that new firms would be created based on the new IT and that these firms would become immensely valuable as they created new intangible capital based on that technology.

Greenwood and Jovanovic point to the Nasdaq index as a reasonable proxy for the value of firms using the new IT. The market value of the typical Nasdaq firm has grown tremendously in relation to GDP, while that of the typical firm in existence since 1968 or before has stagnated.

In this exciting view, the United States has been accumulating capital at a breakneck pace in recent years, as new firms build IT-based infrastructure that will result in high levels of output in future years. Their hypothesis can make sense out of puzzles such as Amazon.com, a company worth $\$ 18$ billion as measured by its stock price despite revenue in 1998 of only $\$ 610$ million and operating losses of $\$ 124$ million. $^{5}$

The IT revolution has not yet begun to produce the high level of output promised by the Greenwood-Jovanovic scenario. If and when that output does come into the market, productivity will jump. So far, however, productivity is still on the track of slow growth that it has followed since the early 1970s, although there are hints of a minor improvement since 1995.

4. Greenwood and Jovanovic (1999).

5. Based on stock price quotation from Yahoo! (www.yahoo.com), June 16, 1999, and Wall Street Journal, March 25, 1999, p. B1. 
More than anything else, the Gale-Sabelhaus paper shows the importance for macroeconomic analysis of the phenomenal rise in the stock market since 1982. I am confident that this paper will help draw researchers into that important topic, which to date has not generated much fruitful research by financial economists.

General discussion: William Nordhaus found the paper very informative and important in light of the current debate on whether the United States is undersaving and underinvesting. He noted that, in a closed economy with perfect foresight, both Hicksian and Fisherian measures of national income exclude capital gains or asset revaluation effects. In such a circumstance, capital gains reflect pure asset revaluation, not changes in the resources available to the economy now or in the future. In other words, revaluation of existing stocks is excluded when it does not reflect an increase in either current production or sustainable consumption. On the other hand, if there is an unanticipated increase in future productivity growth (say, due to a cluster of innovations around the Internet), some of the capital gains might reflect more optimistic estimates of future productivity. In this case, with no change in current consumption or output, there would be no change in Hicksian saving, but Fisherian saving would increase. Additionally, Nordhaus observed, the appropriate definition of national saving might include asset revaluations in an open economy when such revaluations reflect changes in the terms of trade that affect sustainable consumption. For example, if the economy exports oil and imports wheat, a permanent increase in the price of oil relative to wheat increases sustainable consumption.

Nordhaus also discussed the measurement of investment. He stressed that current measures of investment in the NIPAs are flawed because the concept of capital used is much too narrow. One example is the omission of natural resources: the current NIPAs exclude the value of additions and depletions of subsoil assets such as oil and gas. Although omitting changes in oil and gas reserves probably does not change national investment substantially, including a broader set of environmental assets (such as the value of clean air and water) may make a substantial difference to net national saving. Another example of enormous significance is the omission in the national accounts of investment in education, human capital, research and development, and software. Yet another example is health capital. Nordhaus noted studies by Cutler and Richardson, Murphy and 
Topel, and himself indicating that net investment in health capital over the last half century has been enormous because of improvements in life expectancy. He also cited the work of Eisner, who estimates that true national net investment is five times the measured net investment. Nordhaus concluded that the amount of saving and investment in the United States has been vastly underestimated. The view that we are saving nothing because the personal saving rate is near zero not only is wrong but may give a misleading impression of actual trends compared with a broader definition of saving and investment.

Barry Bosworth reiterated that the debate over the inclusion or exclusion of capital gains in income is of long standing. He agreed with Nordhaus that the official measures of saving and investment are extremely narrow from an economist's perspective. On the other hand, he also thought that, although the high stock market valuations of today may be indicative of future rapid productivity growth, there was room for skepticism. In particular, it is unclear that corporations would capture a large fraction of the payoffs to technological innovation in computers and information technology. In his view the value of these innovations will show up as externalities, mainly to workers and households. It seemed to him just a matter of time before Microsoft would lose its monopoly, and he doubted that the extraordinary valuations of Internet stocks would persist.

Benjamin Friedman observed that it was not only not surprising but inevitable that the national saving rate inclusive of capital gains would increase following a major appreciation of asset values. To a first approximation, total output in the short run is given, or at least certainly cannot increase in step with the recent runup in value of the U.S. stock market. Net investment could be squeezed out by higher consumption, but net investment is relatively small to start with. Similarly, the trade deficit could rise, as it has, but again, the magnitude of plausible trade deficits pales in comparison with the magnitude of recent capital gains. Hence the savinginvestment relationship implicit in including capital gains in the definition of income virtually guarantees an approximately parallel increase in saving. 


\section{References}

American Council of Life Insurance. 1998. Life Insurance Fact Book, 1998. Washington.

Antoniewicz, Shelly, and Eric Engen. 1994. "The Measurement of Personal Saving Rates." Washington: Board of Governors of the Federal Reserve. Preliminary.

Auerbach, Alan J. 1985. "Saving in the U.S.: Some Conceptual Issues.” In The Level and Composition of Household Saving, edited by Patric H. Hendershott. Cambridge, Mass.: Ballinger.

Baily, Martin Neil. 1981. "Productivity and the Services of Capital and Labor." BPEA, 1:1981, 1-50.

Blair, Margaret M., and Thomas A. Kochan. 1999. "Introduction.” In The New Relationship: Human Capital in the American Corporation, edited by Margaret M. Blair and Thomas A. Kochan. Brookings. Forthcoming.

Boskin, Michael J. 1986. "Theoretical and Empirical Issues in the Measurement, Evaluation, and Interpretation of Postwar U.S. Saving." In Savings and Capital Formation: The Policy Options, edited by F. Gerard Adams and Susan M. Wachter. Lexington, Mass.: Lexington Books.

Bosworth, Barry, Gary Burtless, and John Sabelhaus. 1991. "The Decline in Saving: Evidence From Household Surveys." BPEA, 1:1991, 183-241.

Bradford, David F. 1990. "What Is National Saving? Alternative Measures in Historical and International Context." In The U.S. Savings Challenge: Policy Options for Productivity and Growth, edited by Charls E. Walker, Mark A. Bloomfield, and Margo Thorning. Boulder, Colo.: Westview Press in cooperation with the American Council for Capital Formation.

__. 1991. "Market Value vs. Financial Accounting Measures of National Saving." In National Saving and Economic Performance, edited by B. Douglas Bernheim and John B. Shoven. University of Chicago Press.

Campbell, John Y., and Robert E. Shiller. 1998. "Valuation Ratios and the LongRun Stock Market Outlook." Journal of Portfolio Management 24(2): 11-26.

Congressional Budget Office. 1993. Assessing the Decline in the National Saving Rate. Washington (April).

Eisner, Robert. 1988. "Extended Accounts for National Income and Product." Journal of Economic Literature. 26(4): 1611-84.

1991. "The Real Rate of U.S. National Saving." Review of Income and Wealth 37(1): 15-32.

Engen, Eric M., William G. Gale, and John Karl Scholz. 1996. “The Illusory Effects of Saving Incentives on Saving." Journal of Economic Perspectives 10 (4): 113-38. 
Fronstin, Paul. 1998. "IRA Assets Grew by 23 Percent During 1997." EBRI Notes 12(December): 3-7. Washington: Employee Benefits Research Institute.

Glassman, James K., and Kevin A. Hassett. 1999. Dow 36,000: The New Strategy for Profiting from the Coming Rise in the Stock Market. New York: Times Books. Forthcoming.

Gokhale, Jagadeesh, Laurence J. Kotlikoff, and John Sabelhaus. 1996. "Understanding the Post-War Decline in U.S. Saving: A Cohort Analysis.” BPEA, 1:1996, 315-90.

Greenwood, Jeremy, and Boyan Jovanovic. 1999. "The Information-Technology Revolution and the Stock Market.” American Economic Review 89(2): 116-22.

Hall, Robert E. 1999. The Stock Market and Capital Accumulation. Stanford, Calif.: Hoover Institution and Stanford University. Unpublished paper (May).

Hendershott, Patric, and Joe Peek. 1989. "Aggregate U.S. Private Saving: Conceptual Measures and Empirical Tests." In The Measurement of Saving, Investment, and Wealth, edited by Robert E. Lipsey and Helen Stone Tice. National Bureau of Economic Research Studies in Income and Wealth 52. University of Chicago Press.

Holloway, Thomas M. 1989. "Present NIPA Saving Measures: Their Characteristics and Limitations." In The Measurement of Saving, Investment, and Wealth, edited by Robert E. Lipsey and Helen Stone Tice. National Bureau of Economic Research Studies in Income and Wealth 52. University of Chicago Press.

Jorgenson, Dale W., and Barbara M. Fraumeni. 1989. "The Accumulation of Human and Nonhuman Capital, 1948-84." In The Measurement of Saving, Investment, and Wealth, edited by Robert E. Lipsey and Helen Stone Tice. National Bureau of Economic Research Studies in Income and Wealth 52. University of Chicago Press.

Kotlikoff, Laurence J. 1989. Testimony before the U.S. House of Representatives, Committee on Ways and Means, April 20.

Larkins, Daniel. 1999. "Note on the Personal Saving Rate." Survey of Current Business 79(2): 8-9.

Maki, Dean M. 1995. "Household Debt and the Tax Reform Act of 1986.” Stanford University Center for Economic Policy Research Publication 436 (November).

Nordhaus, William D. 1995. "How Should We Measure Sustainable Income?" Cowles Foundation Discussion Paper 1101. New Haven, Conn.: Cowles Foundation, Yale University (May).

- 1996. "Budget Deficits and National Saving." Challenge (March-April): 45-49.

Parker, Jonathan A. 1999. "Spendthrift in America? On Two Decades of Decline in the U.S. Saving Rate.” NBER Macroeconomics Annual (forthcoming).

Poterba, James M. 1987. "Tax Policy and Corporate Saving." BPEA, 2:1987, $455-515$. 
Rosen, Sherwin. 1989. "Comment on the Accumulation of Human and Nonhuman Capital, 1948-84." In The Measurement of Saving, Investment, and Wealth, edited by Robert E. Lipsey and Helen Stone Tice. National Bureau of Economic Research Studies in Income and Wealth 52. University of Chicago Press.

Ruggles, Richard. 1993. "Accounting for Saving and Capital Formation in the United States, 1947-1991.” Journal of Economic Perspectives 7(2): 3-17.

Ruggles, Nancy, and Richard Ruggles. 1983. "The Treatment of Pensions and Insurance in National Accounts." Review of Income and Wealth 29(4): 371-404.

Sabelhaus, John. 1998. "Modeling IRA Accumulation and Withdrawals." Washington: Congressional Budget Office (December).

Sabelhaus, John, and David Weiner. 1999. "Disposition of Lump-Sum Pension Distributions: Evidence From Tax Returns." National Tax Journal. Forthcoming.

Schultze, Charles L. 1990. "Discussion on What Is National Saving? Alternative Measures in Historical and International Context." In The U.S. Saving Challenge: Policy Options for Productivity and Growth, edited by Charls E. Walker, Mark A. Bloomfield, and Margo Thorning. Boulder, Colo.: Westview Press in cooperation with the American Council for Capital Formation.

Steuerle, C. Eugene. 1990. "Federal Policy and the Accumulation of Private Debt." In Debt, Taxes and Corporate Restructuring, edited by John B. Shoven and Joel Waldfogel. Brookings.

Summers, Lawrence H., and Christopher Carroll. 1987. "Why Is U.S. National Saving So Low?" BPEA, 2:1987, 607-35.

Weitzman, Martin L. 1976. "On the Welfare Significance of National Product in a Dynamic Economy." Quarterly Journal of Economics 90(1): 156-62.

Wilcox, David W. 1991. "Household Spending and Saving: Measurement, Trends, and Analysis." Federal Reserve Bulletin 77(1): 1-17.

Wilson, John, and others. 1989. "Measuring Household Saving: Recent Experience from the Flow-of-Funds Perspective." In The Measurement of Saving, Investment, and Wealth, edited by Robert E. Lipsey and Helen Stone Tice. National Bureau of Economic Research Studies in Income and Wealth 52. University of Chicago Press. 